the capital stock as such could be taxed was repudiated. The State can no more tax the capital stock of a foreign corporation than it can tax the capital of a foreign person. Pennsylvania cannot tax a citizen and resident of New York, either for the whole or any part of his general property or capital. It can only tax such property of that citizen as may be located and have a situs in Pennsylvania. 'And it is exactly the same with a foreign corporation. Its capital, as such is not taxable. ${ }^{2}$ To hold otherwise would lead to the most oppressive and unjust proceedings. It would lead to a course of spoilation and reprisals that would endanger the harmony of the Union.

\title{
STATE TAXATION OF PROPERTY USED FOR PURPOSES OF INTERSTATE COMMERCE.
}

The practical wisdom and political foresight of the men who framed the Constitution are nowhere, perhaps, better illustrated than in the adoption of the Commerce Clause. The subsequent experience of the country has shown that the people of the several States, from motives of pure selfinterest, are prone to foster their own interests at the expense of the interests of their neighbors, and to shift the burden of the support of their several governments as much as possible from their own shoulders to those of the citizens of the other States. But in attempting to accomplish these ends the States have frequently found themselves confronted by the Commerce Clause of the National Constitution, and the firm stand which the Supreme Court has always maintained in the construing that clause has invariably frustrated such selfish designs, and has contributed not a little to the political harmony and economic welfare of the country.

In the great case of Brown v. Marjland, 12 Wh. 419, (1827), which, with the somewhat earlier case of Gibbons v. Ogden, 9 Wh. I, (I824), forms the foundation upon which has been reared the whole structure of Interstate Commerce law, Chief Justice Marshall, speaking of the taxing power of the State, said: "We admit this power to be sacred; but cannot admit that it may be used so as to obstruct the free exercise of a power given to Corgress. We cannot admit that it may be used so as to defeat the power to regulate commerce. It has been observed that the powers remaining with the States may be so exercised as to come in conflict with those vested in Congress. When this happens that which is not supreme must yield to that which is supreme. This great and universal truth is inseperable from the nature of things, and the constitution has applied it to the often interfering powers of the general and State governments as a vital principle of perpetual operation. It results, necessarily, that the taxing power of the State must have some limits."

And Mr. Justice Strong, in the case of State Freight Tax, I5 Wall. 282 ( 1871 ), says: "While upon

I State Tax on Foreign held Bonds, 15 Wall.

2 Gloucester Ferry Company v. Peznsylvania, qua supra, 
the one hand it is of the utmost importance that the States should possess the power to raise revenue for all purposes of a State government, by any means, and in any manner not inconsistent with the powers which the people of the States have conferred upon the general government, it is equally important that the domain of the latter should be presérved free from invasion, and that no State legislation should be sustained which defeats the avowed purpose of the Federal Constitution, or which assumes to regulate or control subjects committed by the Constitution exclusively to the regulation of Congress." And in Philadelphia S. S. Co. v. Pernna., 122 U. S. $3^{20}$, (I886), Mrr. Justice BRADLEy says: "The result of all the cases is that the corporate franchises, the property, the business, the income of corporations may undoubtedly be taxed by the State, but in imposing such a tax, care should be taken not to interfere with or hamper, directly or by indirection, interstate or foreign commerce, or any other matter exclusively within the jurisdiction of the Federal Government. This is a principle so often announced that it may be said to be an axiom of our Constitutional jurisprudence.

The great majority of cases involving a consideration of the limits which the commerce clause imposes upon the taxing powers of the States have arisen out of attempts of the States to lay taxes upon the business or occupation of carrying on interstate commerce. With this line of cases, in the present inquiry, we have nothing to do. It is sufficient to say that the invalidity of such taxes is now almost universally recognized. Nor need we concern ourselves with that other large class of cases which deals with State taxes upon the articles or subjects of commerce in which an interstate traffic is actually being carried on, and which have not be- come merged in the common mass of property within the State. It may be said of such taxes, also, that their invalidity is now pretty generally conceded. The present inquiry will therefore be limited to a consideration of the validity of State taxes upon property not in itself a subject or article of interstate commerce, but employed as a means or instrumentality for carrying on the same.

The earliest case on this subject is that of Hays v. Pacific Mrail S. S. Co., How. 596 (1854). The plaintiff was a New York corporation, and operated a line of steamships between New York and San Francisco. After landing cargo and passengers at San Francisco, the vessels usually proceeded to another California port, where they laid up for a week or so before starting on the return voyage. The vessels were registered at New York, where the corporation had its principal office, and where all the stockholders resided. Under these circumstances, the State of California levied a tax upon the vessels as property within the State. The Court held that the State of California had no jurisdiction over these vessels for the purposes of taxation; they were not, properly, abiding within its limits, so as to become incorporated with the other personal property oi the State; they were there but temporarily, engaged in lawful trade and commerce, with their silus fixed by the Act of Congress at their home port, where they were required to be registered, and where their owners were liable to be taxed for the capital invested, and where the taxes had been paid. "Whether a vessel leaving her home port for trade and commerce, visits in the course of her voyage several ports, or confines her operations to one, are questions that will depend upon the protitable returns of the business, and will furnish no more evidence that she has become 
a part of the personal property within the State, and liable to taxation at one port than at the others. She is within the jurisdiction of all or any one of them temporarily, and for a purpose wholly excluding the idea of permanently abiding in the State, or changin ${ }_{5}$ her home port. Our merchant vessels are not unfrequently absent for years, in the foreign carrying trade, seeking cargo, carrying and unloading it from port to port, during all the time absent; but they neither lose their national character nor their home port as inscribed upon their stern. The distinction between a vessel in her home port and when lying in a foreign one, or in the port of another State, is familiar in the admirality law. She is subjected, in many cases, to the application of a different set of principles." In other words, the settled custom of maritime nations has always been to consider vessels as property whose situs is in the country in which they they belong, and in no sense as property of the country to which they come on their voyages, and the Act of Congress has extended this principle as between the several States, so that California had no more jurisdiction to tax the vessels in question than she would have had had they belonged in a foreign country.

This case was followed in the case of Morgan v. Parham. I6 Wall., $471(18,2)$, in which the facts were substantially the same. The city of Mobile assessed one of several steamships plying between Mobile and New Orleans, as personal property of the plaintiff in the City of Mobile, and levied a tax thereon. The vessel was registered at New York, where her owner resided. She was also enrolled at Mobile. Speaking of the effect of registry and enrollment the Court says : "Permanent registry is required to be made at the home port, and the Act provides that the name of the vessel and the port to which she shall so belong shall be printed on her stern. All persons, therefore, have the means of ascertaining the name of the vessel and her home port, and her shipping papers, which include a copy of her register or enrollment, are by law required to furnish the same information. The Act prescribes the terms and shows the effect of enrollment at another port. In substance the permanent register is given up to the collector of that port, and a certificate is issued showing the name of the vessel, the port to which she belongs and that to which she is destined. This certificate is temporary in its character, and is based upon the proposition that the vessel belongs or has her home port, at a different place from that at which she receives this certificate. There was nothing, therefore, in her enrollment in the port of Mobile that affected her registry in New York, or her ownership in that place, or that tended to subject her to taxation by the State of Alabama, under the circumstances stated. In the opinion of the Court the State of Alabama has no jurisdiction over this vessel for the purpose of taxation for the reason that it had not become incorporated into the personal property of that State, but was there temporarily, only, and that it was engaged in lawful commerce between the States with its situs at the home port of New York, where it belonged and where its owner was liable to be taxed for its value."

And to the same effect in St. Louis v. The Wiggins Ferry Co., II Wall., 423 (1870). In Wheeling Transportation Co. v. Wheeling, 98 U. S., $273(1878)$, the question was raised whether vessels engaged in interstate commerce could be taxed as property by the State or municipality in which their home port was situated and in which their owners resided. The Court held that since the vessels were property belonging to the citizens of the State they were 
liable to taxation there in the same manner as other property, and that there was nothing in the National constitution, or in the fact that the vessels in question were licensed to carry on the coasting trade which would render such a tax be invalid. There are many cases in which the Courts in denying the power of the States to lay duties of tonnage, have admitted that the owners of ships may be taxed to the extent of their interest in the same, for the value of the property. Assessments of the kind, when levied for muncipal purposes, must be made against the owner of the property, and can only be made in the municipality where the owner resides. "Decided cases of the kind every" where deny to the States the power to tax ships as the instruments of commerce, but they all admit, expressly or impliedly, that the State may tax the owners of such property for their interests in the same. Corresponding views are expressed by Mr. Burroughs in his valuable treatise upon taxation. He says that vessels of all kinds are liable to taxation as property in the same manner as other personal property owned by the citizens of the State; that the prohibition only comes into play where they are not taxed in the same way as the other property of the citizens, or where the tax is imposed upon the vessel as an instrument of commerce without reference to the value as property." 1 his case is authority, therefore, for the proposition that property used for the purposes of interstate commerce is not, on that account, exempt from taxation. which is otherwise proper.

The case of Wiggins Ferry Co. v. Exst St. Loutis, 107 U. S. 365, (1882), carries this doctrine much further. The city had passed an ordinance requiring all persons and corporations engaged in certain businesses and professions to take out licenses, and further provided that "Keepers of Ferries shall pay \$roo license for each boat plying between this city and the opposite bank of the river for one year." Under this ordinance the City brought an action against the Wiggins Ferry Co. a corporation of the State, operating a ferry across the Mississippt, to recover the license fee. The Court held, Mr. Justice Woods writing the opinion, that the levying of a $\operatorname{tax}$ upon vessels, or, the exaction of a license fee, by the State within which the property subject to the exaction has its situs, is not a regulation of commerce within the meaning of the Coustitution of the United States. "The exaction of a license fee is an ordinary exercise of the police power by municipal corporations. Where, therefore, a State expressly grants to an incorporated City, as in this case, the power to license, $\operatorname{tax}$ and regulate ferries, the latter may impose a license $\operatorname{tax}$ on the keepers of the ferries, although their boats ply between landings lying in two different States, and the Act by which this exaction is authorized will not be held to be a regulation of commerce." It may be said in passing, that in the light of the more recent decisions it may well be doubted whether the doctrine thus broadly laid down would be adhered to at the present time, and whether, on a similar state of facts, such a tax would now be held valid. And it is to be observed that the decision is confined to boats used in operating a ferry, and there has always been a tendency in the cases to regard ferries as more appropriately under State control than other branches of interstate commerce, for when the City of New Orleans required a similar license from persons or corporations running boats to or from the Gulf of Mexico, the exaction was held invalid. Moran v. New Orleans, II2, U. S. 68. (I884).

Considerable stress is laid in the majority opinion upon Gloucester Ferry Co. v. Penna., II4, U. S. 
I96, (1884). The facts of that case were as follows: The State of Pennsylvania enacted a law providing that every corporation doing business within the State should pay a tax at a certain rate upon its capital stock. The Gloucester Ferry Co. was a New Jersey corporation, which operated a line of ferry boats across the Delaware River, between Philadelphia and Gloucester. The company leased a wharf within the former city, but the boats were registered in Camden. The State of Pennsylvania claimed that leasing a wharf within the State and landing and receiving passengers at it was "doing business" within the State, and that therefore the whole capital stock was liable to taxation in Pennsylvania.

The Court held that while corporations might be taxed in Pennsylvania for the value of the wharf which it leased there, it could not be taxed in the manner above described, for as Chief Justice MIARshall said, "The power of taxation, however vast in its character and searching in its extent, is necessarily limited to subjects within the jurisdiction of the State." And the Court went on to say, quoting from Pennsylvania v. Staudard Oil Company, ror Pa. II9, (IS广̀), that it had been repeatedly decided, and was settled law, that a tax upon the capital stock of a company is a tax upon its property and assets. Since the company was not domiciled in Pennsylvania, and had none of its capital invested there, the boats being registered in New Jersey, it followed that the tax was laid solely on account of the business of the company in landing and receiving passengers at the wharf in Philadelphia, and that business was an essential part of the transportation between the States of Penusylvania and New Jersey, which is itself interstate commerce. "While it is con"ceded that the property in a State "belonging to a foreiorn corporation
" engaged in foreign or interstate com-

"merce may be taxed equally with "like property of a domestic corpor"ation engaged in that business, we " are clear that a tax or other burden " imposed on the property of either "corporation because it is used to "carry on that commerce, or upon the " transportation of persons of property " or for the navigation of the public " waters over which the transporta"tion is made, is invalid and void as " an interference with and an obstruc" tion on the power of Congress in the "regulation of.sucl commerce." And the Court also held that the fact that the company was engaged in operating a ferry could not authorize the imposition, by the State, of taxes or other burdens upon commerce between the States.

It will be seen that the tax in question was held invalid because it was in no sense a tax upon the property of the corporation equally with the other property within the State, inasmuch as the property sought to be taxed was never within the State, and the case, accordingly, apart from the expressions that were used, has very little bearing upon present inquiry.

The two cases of Brown v. Houston, II4 U. S., 922 ( $188_{4}$ ), and Coe v. Errol, I16 U. S., 517 (1885), cited in the majority opinion, dealt with State taxation of the articles or subjects of commerce. In the first case, 2 cargo coal had been sent from Pittsburg to agents in New Orleans, to be by them sold. While laying at the wharf, and before the agents had succeeded in selling it, it was assessed as movable property within the city belonging to them, and they were compelled to pay a tax thereon. The Supreme Court upheld the tax, holding that the cargo had become merged in the general mass of property within the State. And in the case of Coe v. Errol, the Court held that articles of commerce were not exempt from locai taxation until they had actually started on 
their interstate journey. Nor was it material that the goods in question were owned by persons residing in another State. "We take it to be a point settled beyond all contradiction or question, that a State has jurisdiction of all persons and things within its territory which do not belong to some other jurisdiction, such as the representatives of foreign governments, with their houses and effects, and property belonging to or in the use of the governments of the United States. "If the owner of personal property within the State resides in another State which taxes him for that property as a part of his general estate attached to his person, this action of the Iatter State does not in the least affect the right of the State in which the property is situated to tax it also. It is hardly necessary to cite authorities on a point so elementary." And, though the point was not actually before them, the Court cited with approval the decision of the Court below that goods merely passing through a State, but detained there temporarily by accident or stress of weather, had no situs there for purposes of taxation.

The case Pickard v. Pullman Co., 117 U. S. 34, (1885) is an important one in this connection. The Legislature of Tennessee passed an Act providing that "the rumning and using of sleeping cars on railroads in Tennessee, not owned by the railroad upon which they were used, is declared a privilege, and the companies owning and running or using said cars are required to pay $\$ 50$ a year for each and every one of said cars used or run over said roads." Under this Act a tax was imposed upon the Pullman Company for thirty-six cars owned by them and used by various railroads in Tennessee for the trans portation of passengers, within, into, out of and through Tennessee. The tax had been held invalid by Mr. Justice Matthews, in the Circuit Court. and the Supreme Court took the same view. The Court pointed out that the tax was not a property tax, because under the constitution of Tennessee property could only be taxed according to its value, and this tax was an arbitrary charge. What was done by the company was taxed as a privilege. The tax was imposed as a condition precedent to the right 0 the company to run and use the cars owned by it, as it ran and used them, on railroads in Tennessee, and upon principie the tax if lawful might have been large enough to practically stop altogether this particular species of commerce. It was contended that the business of the company was merely to furnish extra accommodations or comforts, and that a burden upon it was not a burden upon interstate commerce. But the Court held that the tax was really one on the right of transit. though laid wholly on the owner of the car. So, too, the service rendered to the passenger was a unit. The car was as much a vehicle of transit, as if it had been a car owned by the railroad company, and the special conveniences or comforts furnished to the passengers had been furnished by the railroad company itself. "The fee paid by the interstate passenger to the railroad company, and that paid to the plaintiff added together, were merely a charge for his conveyance in a particular way, and there was really but one charge for the transit, though the total amount paid was divided among two recipients. The service was a single one, of interstate transit, with certain accommodations for comfort, and what was paid to the company was part of a charge for the conveyance of the passenger." The Court accordingly held that the tax was virtually a tax upon the interstate transportation of passengers and therefore void. The results of this case may accordingly be summed up by stating that it is authority for the proposition that the 
State cannot levy an arbitrary charge, at so much a car, upon companies owning or using cars employed in conducting interstate commerce.

The case of Western Union Telegraph Co. v. Altomey-General of Massachusetts, 123 U. S., 630 (1887). forms a bone of contention between the majority and the minority in the principal case. Mr. Justice BRADLEY, however, took no part in that decision, not having heard the argument. The tax in question in that case was one imposed on the proportion of capital stock supposed to be invested in Massachusetts, taking as a basis of assessment such proportion of the value of the entire capital stock of the company as the length of the company's lines within the State bore to their entire length throughout the country. The Court said that the tax, though nominally upon the capital stock of the company, was in effect a tax upon that organization on account of property owned and used by it in the State of Massachusetts. It was urged that the method of assessment employed was not an accurate one, and that the property of the company situated in Massachusetts had no necessary relation to the proportion of capital stock taxed, because the aggregate value of the stock might depend upon property, franchises and business outside of Massachusetts, largely out of proportion to the telegraph lines outside of that State. But the Court said : " since this statute of Massachusetts is intended to govern the taxation of all corporations therein, and doing business within its territory, whether organized under its own laws or those of some other State, and since the principle is one which we cannot pronounce to be an unfair or an unjust one, we do not feel called upon to hold the tax void because we might have adopted a different system had we been called upon to accomplish the same result." And the Court also said that in their opinion, in view of the importance of the business done in Massachusetts, the method employed was anything but unfavorable to the company.

It will be observed that the above case, while it has several points of similarity with the principal case, has also some points of difference. These are emphasized by Mir. Justice BRADley in his dissenting opinion. He says : "The same difficulty as to the method of determining value exists in this case which existed in that; but the more serious difficulty lies in the question of the situs of the property, and the consequent jurisdiction of the State of Pennsylvania to $\operatorname{tax}$ it. It is not fast property ; it does not consist of real estate ; it does not attach itself to the land; it is movable, and engaged in interstate commerce, not in Pennsylvania alone, but in that and other States, and the question is, How can such property be taxed by a State to which it does not belong? It is indirectly, but virtually taxing the passengers. It is clearly a burden on interstate commerce." But passing, for the moment, the difficult question of situs, and assuming that the State of Pennsylvania had jurisdiction, for the purposes of taxation, of such cars, then it would seem that Telegraph Co., v. Massachusetts is conclusive of the question whether such a tax is a burden upon interstate commerce. The tax upon the cars as property, under a proper valuation, is no more an indirect tax upon the passengers carried than was the tax upon the property of the telegraph company, under a similar method of valuation, a $\operatorname{tax}$ upon the messages sent. However much the fact that the cars are movable, and are, in fact, moved from State to State, may affect their sifus as to State taxation, it cannot affect. the question as to whether such taxation is a burden upon interstate commerce. 
The case of Marye. v. $B$. \& $O$. R. R. 127 U. S. $117,(1887)$, is sufficiently stated by the Court in the majority opinion. But Mr. Justice Gray, in quoting from the opinion of Mr. Justice Matthews in that case, refers to it as "the unanimous judgment of the Court." But it should be remembered that though it is true no one dissented, yet the portion of the opinion referred to was as pure a dictum as is often found in the reports. The Court had already decided that the Statutes of Virginia imposing taxation did not apply to the property in question, and this of course disposed of the case, for there was no longer any law whose validity was to be determined. What was said beyond this was upon the authority only of the writer of the opinion, and while not questioning the accuracy of Mr. Justice Matthews' reasoning in the passage quoted, we simply call attention to the fact that it was not necessary for the decision of the case, and hence it cannot be inferred with certainty that all the other members of the Court entertained the same ideas.

Pullman Palace Car Co. v. Hay. ward, 14r U. S. 36, (189r), a case coming up from Kansas, was argued at the sanie time as Pullman's Co. v. Pennsylvania and was said by the Court to be governed by the same principles. The tax differed slightly from that in the Pennsylvania case, inasmuch as it was not laid upon the company owning the cars but upon the railroad companies that used them. The tax was apportioned among the various counties of the State according to the railroad mileage therein, and although it is not distinctly stated, and the statutes quoted do not clearly require it, it is quite probable that the tax was also apportioned in like manner among the various States in which the cars were used. If this were not the method employed the case could not have fallen within the principles of the first case.
This completes the list of cases on this subject in the United States Supreme Court. There have been various cases in the State and Circuit Courts which have nut gone up to that tribunal for final decision. The case of Pullman Company v: Twombly, 29 Fed. R. 658 , in the U. S. Circuit Court of Iowa, however, though falling directly within Pullman Co.v. Hoyicard, Supra, contains such a clear statement of the law by Judge Brewer, now a Justice of the Supreme Court, and one of the majority in the principal case, as to be worthy of examination.

The State of Iowa taxed the railroad companies within the State for all sleeping and dining cars used, but not owned by them, but only upon a proportion of their value equal to the proportion of their mileage within the State. Judge Brewer remarked that in the absence of any legislation by Congress, similar to that in regard to vessels, fixing the "home port" or situs of personal property engaged in interstate commerce, the most convenient rule must govern. This was not the case of cars owned in other States and only making single trips to the State of Iowa, but of cars which were found, and found continously, in the Slate of Iower, and which consequently acquired a situs there for the taxation. If this were not so, and the cars could only be taxed in the domicile of the owner, then that domicile might not be in any of the States in which the cars were usedmight even be in a foreign countryand yet each of these States would be bound to afford the cars protection. The conclusions of the learned Judge were as follows :

( (I) "That property is not exempt from liability to an equal and uniform tax, by the fact that it is used either particularly or exclusively for interstate commerce. (2) That vehicles of transportation used continuously upon a single run, acquire a silas for pur- 
poses of taxation, independent and irrespective of the domicile of the owner. (3) Such situs is not destroyed by the fact that the owner owning many vehicles of like sharacter, and having lines in various parts of the United States, transfers from time to time, such vehicles from one line to another, provided a continuous use of such vehicles is preserved upon the single run. (4) When such velicles are used upon a run extending through two or more States, there is a situs for taxation in each State, to a fair proportion of the value of the property so used."

The case of Pennsyluania v. Standard Oil Co. Ior Pa. S. I19, (1882). decided by the Supreme Court of Pennsylvania, which we referred to in commenting on Gloncester Ferry Co. r. I'enusylvauia, is a similar case to the latter, but has not as much bearing on this inquiry, since there was no question of interstate commerce raised. The contention in that case was that the Standard Oil Co., an Ohio corporation, which owned interests in certain corporations and individual partnerships in Pennsylvania, was doing business within the State, and, under the statutes, liable for a tax upon its entire capital. The Court lield that except as to the interests in individual partnerships, the corporation was not doing business in Pennsylvania, and that as to those it could only be taxed upon a portion of its capital stock equal to the value of those interests. This was because, as settled by a large number of cases, a tax upon the capital stock of a corporation is a tax upon its property and assets, and therefore the company was only taxable for such portion of its property as was actually within the State. It was contended that by doing business within State the company brought its entire capital withm the jurisdiction of Pennsylvania. But the Court said: "A foreign corporation has no domicile here, and can have none; hence it cannot be said to draw to itself the constructive possession of its property located elsewhere."

It is not often we find a State Court going farther than, or even as far as, the Supreme Court in restricting the powers of the State, but in the case of Bain v. Richmond \& Danville $R R$. Co., $3 I$ I. C. R., I49 (1Sgo), the Supreme Court of North Carolina took a more advanced stand than even the Supreme Court would probably have taken. The Richmond \& Danville R. Co., being a Virginia corporation and being taxed there on its rolling stock, leased certain roads in North and South Carolina and sent its trains over them. The State of North Carolina levied a tax upon rolling stock of the company, which was constantly passing to and fro across the State, in the course of interstate commerce. The State Supreme Court held that the statutes imposing taxation had reference only to property which had a situs in the State, and that the property in question had no such situs. The mere fact that the property of the company of the value mentioned was continuously within the State did not give it a situs there. It was continually changing and in transitu in the course of interstate commerce. "It is true that such property receives protection from the State, and has the benefit of its laws, but nevertheless it is not the subject of taxation, because the Constitution of the United States will not allow it to be made such subject."

Now we think the last statement goes farther than the cases warrant. As we have seen, the cases all admit that property employed in interstate commerce is not, on that account, exempt from taxation as property. If it were, much of the most valuable city real estate, namely, most of the warehousts, offices and stores, would be exempt. Where taxes $h$ ve been 
declared invalid it was because they were not property taxes, or were void for some reason apart from the commerce clause of the Constitution. The cases which establish the immunity of vessels from taxation except in their home ports depend, as we have endeavored to show, upon totally different principles.

It is, indeed, only by a considerable. stretch of the imagination, that a vessel, which merely enters the port of a State at frequent intervals, can be considered as in any sense property within the State. But even if it could be so considered, the long usage of maritime nations-recognized by the laws of the United States, in regard registry - has established the universal doctrine that vessels are only taxable in their home ports. Now, there is no such usage or principle in regard to railroad rolling-stock and, moreover, its nature and use are fundamentally different from the nature and use of vessels. Vessels are on the public highway of nations for the greater portion of the time, and so entirely beyond the jurisdiction of any one country, and so, if they are to have any situs at all, it must be at the domicile of their owner. Rollingstock, on the other hand, though it may be constantly and continually moving from place to place, is always within the jurisdiction of some State, and subject, to a large extent, to the laws and regulations thereof. And it is approximately true of most rolling stock, and absolutely so of sleeping cars, that they are not built for use only within the State of their owner's domicile, but are expressly intended for use in other jurisdictions, and may never return to that in which they are owned. Their use, and therefore, their value, also, is distributed over several jurisdictions, and it would seem to follow, as a necessary consequence, that that value may be taxed in each jurisdiction to the extent to which it actually exists therein, pro- rided that can be satisfactorily determined.

It is true that such a doctrine may not be altogether consistent with the accepted principles in regard to the silus of personal property, and its liability to taxation, but those principles were not formed with reference to problems like the present, and it is the glory of our system of law that its rules and principles are capable of being molded from time to time, to accommodate the system to changing conditions and circumstances. Many such changes have been necessitated by modern inventions and modes of life, and by nothing so much as by the enormous growth and ramifications of railroads, and the position of paramount importance which they have assumed in all departments of business. In all such cases the conservatism of the law must yield to the superior needs of the public walfare. As Judge Brewer says, "The most convenient rule must govern." It was evidently the obvious convenience of the rule in question which led to its adoption by the Court, and it is difficult to see how a better one could have been devised, and the opposite proposition, namely that when cars are in Pennsylvania every day and in New York every night, both States are deprived of the power to tax them, is not one which commends itself to the common sense of a practical age.

Nothing is said, either in the statement of facts or in the opinion, as to whether the Pullman Company was taxed upon the entire capital stork at its domicile. Whether it were or not, could not have influenced the decision. If the owner of personal property, who pays taxes at his domicile for such property, as part of his general estate attached to his person, sends it into another jurisdiction, and is taxed for it there also, this only is a burden or obligation incident to the ownership of such property, arising from the dual position he has as- 
sumed. As a citizen he owes certain duties and obligations to the States of his domicile, of the extent of which his entire property, wherever situated, may well be taken as a measure; and as his property in other States receives protection therefrom, he may be called upon to pay taxes therein to the extent of such protection.

In regard to some of the illustrations used in the dissenting opinion, we think we are justified in saying that they are somewhat misleading. For example, Mr. Justice BRADLEY says: "Certainly property merely carried through a State cannot be taxed by the State. Such a tax would be a duty, which a State cannot impose. If a drove of cattle is driven through Pennsylvania from Illinois to New York, for the purpose of being sold in New York, whilst in Pennsylvania, it may be subject to the police regulations of the State, but it is not subject to taxation there. It is not generally subject to the laws of the State, as other property is. So if a train of cars starts from Cincinnati for New York and passes through Pennsylvania, it may be subject to the police regulations of the State whilst within it, but it would be repugnant to the Constitution of the United States to tax it. We have decided this very question in the case of State Freight Tax." I5 WVall. 232, (1872).

Ve have italicized the phrase "for the purpose of being sold in New York," because it illustrates the essential difference between the two illustrations, and destroys any parallel that might otherwise be drawn between them. No doubt, if the cars in question in the case were only being taken across the State, for the purpose of being sold, they would have been exempt from taxation. They would then have been articles of commerce, in actual course of transportation for purposes of inter- state commerce, and as such exempt from State taxation, as is established by a long line of cases. This was what was decided in the State Freight Tax Case. As it was, the cars were in no sense articles of commerce, but only instrumentalities thereof, the distinction between which, and the different principles governing each, have frequently been pointed out in the cases. It is certainly a somewhat novel idea that such cars could be considered as in any sense imports, so that a tax would be a duty.

False analogies and false parallels have done a great deal to confuse this subject, and to obscure the fact that the commerce clause of the Constitution has really nothing to do with the validity of a tax like the one under consideration. It is purely and simply a question of the situs of personal property; and the decision should be regarded as having laid down a new principle in that branch of the law rather than in that of interstate commerce. It is, however, none the less important on that acconnt.

This case establishing as it does, the validity of the Pennsylvania law, will undoubtedly lead to the enactment of similar laws by other State Legislatures. Should any State overstep the latitude allowed it, and attempt to tax the full value of cars employed in interstate commerce, it may become necessary for the Supreme Court to point out that this decision does not at all infringe upon the well established principle, that a State can only tax persons and property within its jurisdiction, and that the jurisdiction over cars employed in interstatecommerce, is not an absolute one, but restricted within well defined limits, which the States are powerless to transgress. By this it is not meant to insinuate that the decision of the Court in this case is a piece of judicial legislation. In truth it is not such, but only an illustration of the fact that in all cases involving the 